
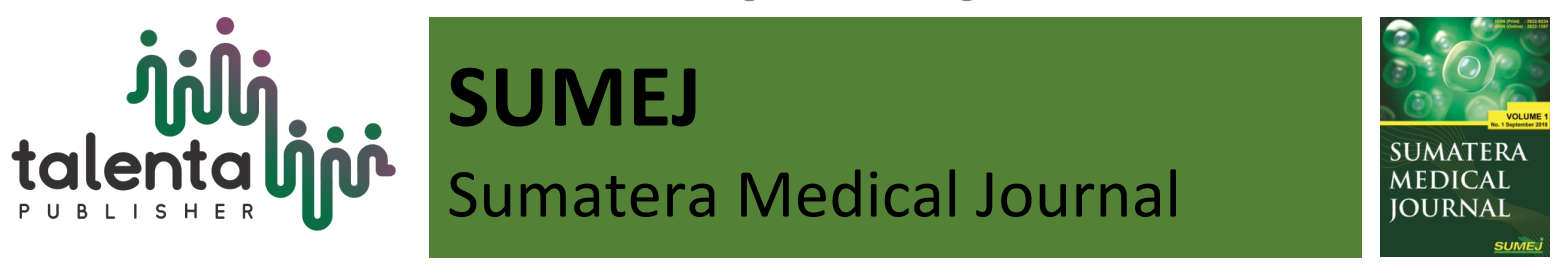

\title{
The Relationship of ICH Score and 30-Day Mortality Rate in Hemorrhagic Stroke Patient: Systematic Review and Meta-Analysis
}

\author{
Samuel Adithya Pratama Sitohang ${ }^{1^{*}}$, Sabri ${ }^{2}$ \\ ${ }^{I}$ Faculty of Medicine, Universitas Sumatera Utara, Medan, Indonesia \\ ${ }^{2}$ Department of Neurosurgery, Universitas Sumatera Utara, Medan, Indonesia
}

\begin{abstract}
Hemorrhagic stroke is a type of stroke that causes more deaths than ischemic stroke. The prognosis of hemorrhagic stroke patients can be determined with ICH Score. ICH score has a value range of $0-6$. The variables of ICH Score are GCS score (0-2), bleeding volume (0-1), intraventricular bleeding (0-1), infratentorial origin (0-1), and age (0-1). Aim: This meta-analysis study aims to determine the relationship between ICH Score and 30-day mortality rate in hemorrhagic stroke patients. Methods: This meta-analysis study uses online literature sourced from Pubmed, Science Direct and Google Scholar. Result: Based on data analysis, there is a significant relationship between the ICH Score and the mortality rate in hemorrhagic stroke patients (OR 18.04, 95\% CI: 10.65; 30.55). Analysis of the ICH Score accuracy found that the ICH Score had high accuracy to predict the mortality of hemorrhagic stroke patients (AUC $0.827,95 \%$ CI: 0.796; 0.858). Conclusion: ICH Score has a significant relationship with the 30-day mortality rate in hemorrhagic stroke patients and has high accuracy for predicting mortality in hemorrhagic stroke patients.
\end{abstract}

Keyword: Hemorrhagic Stroke, ICH Score, Mortality Rate

\begin{abstract}
Abstrak. Stroke hemoragik merupakan jenis stroke yang lebih banyak menyebabkan kematian dibandingkan stroke iskemik. Prognosis dari pasien stroke hemoragik dapat ditentukan dengan ICH Score. ICH Score memiliki rentang nilai 0-6. Variabel dari ICH Score adalah skor GCS (0-2), volume perdarahan (0-1), perdarahan intraventriikular (01), perdarahan infratentorial (0-1) dan umur (0-1). Tujuan: Penelitian meta-analisis ini bertujuan untuk menentukan hubungan ICH Score terhadap angka mortalitas pada pasien stroke hemoragik. Metode: Penelitian meta-analisis ini menggunakan literatur online yang bersumber dari Pubmed, Science Direct dan Google Scholar. Hasil: Berdasarkan analisis data, didapati adanya hubungan yang signifikan antara ICH Score dan angka mortalitas pasien stroke hemoragik (OR 18.04, 95\% CI: 10.65; 30.55). Analisa akurasi ICH Score menemukan bahwa ICH Score memiliki akurasi yang tinggi untuk memprediksi kematian pada pasien stroke hemoragik (AUC 0.827, 95\% CI: 0.796; 0.858). Kesimpulan: ICH Score memiliki hubungan yang signifikan terhadap angka mortalitas 30 hari pada pasien stroke hemoragik dan memiliki akurasi yang tinggi untuk memprediksi kematian pasien stroke hemoragik.
\end{abstract}

Kata Kunci: Stroke Hemoragik, ICH Score, Angka Mortalitas

Received date month year | Revised date month year | Accepted date month year

*Corresponding author at: Faculty of Medicine, Universitas Sumatera Utara, Medan, Indonesia

E-mail address: samueladithya77@gmail.com 


\section{Introduction}

Stroke is a cerebrovascular disease that causes neurological deficit that occurs suddenly due to cessation of blood supply to the brain, resulting in disruption of brain function. Impaired cerebral blood flow can be caused by ruptured artery or blockage in the brain blood vessels [1]. There are several risk factors of stroke which include hypertension, diabetes, atrial fibrillation, cholesterol, smoking, lack of physical activity, family history, and kidney disease [2].

Based on data from American Heart Association (AHA), 33 million people worldwide had stroke experience and 16,9 million were the first cases of stroke [3]. In Indonesia, the stroke prevalence has increased from 7 per 1000 population in 2013 to 10.9 per 1000 population in 2018 with the highest prevalence in people aged $\geq 75$ year [4].

Hemorrhagic stroke can be classified into primary hemorrhagic stroke and secondary hemorrhagic stroke. In primary hemorrhagic stroke, more than 50\% cases are associated with hypertension and the rest are associated with cerebral amyloid angiopathy (CAA). In the other hand, secondary hemorrhagic stroke mostly caused by aneurysm, arteriovenous malformation, oral anticoagulant use, coagulopathy, neoplasm, trauma, vasculitis, moyamoya disease, and venous sinus thrombosis [5]. Based on the bleeding location, hemorrhagic stroke can be classified into intracerebral hemorrhage (ICH), subarachnoid hemorrhage (SAH), and intraventricular hemorrhage (IVH) [6].

The intracerebral hemorrhage (ICH) score is a clinical grading scale that used to determine the prognosis of patients with intracerebral hemorrhage. ICH score can accurately predict 30-day mortality rate of hemorrhagic stroke patient. Variable of ICH score is GCS score, bleeding volume, intraventricular bleeding, infratentorial origin, and age [7]. The score for each variable of ICH score can be seen in Table 1.

\section{Methodology}

This meta-analysis using online publication studies from Pubmed, Science Direct, and Google Scholar by using the search phrase "Hemorrhagic Stroke" AND "ICH Score" AND "Mortality Rate". The purpose of this study is to determine the relationship between ICH score and 30-day mortality rate in hemorrhagic stroke patient. Inclusion criterias are have non-traumatic hemorrhagic stroke patients as study subject and have ICH score which can be calculated to determine the size of effect (Odds Ratio/Risk Ratio and Area Under Curve). Review articles, comments, and study conducted in children are excluded from this study. The data analysis in this study using 2 applications, Revman 5.4 and MedCalc.

\section{Result}

A total of 20 studies that meets the inclusion criteria were used in this study. Nine studies only showed data to determine relationship between ICH score and 30-day mortality rate and the other 
nine showed data to find out how accurate ICH score. The remaining two studies show both data.. Characteristic of the studies can be seen in Table 2.

Table 1 Variables of ICH Score

\begin{tabular}{lc}
\hline Variable & ICH Score \\
\hline GCS Score & 2 \\
$3-4$ & 1 \\
$5-12$ & 0 \\
$13-15$ & \\
Volume ICH $\left(\mathrm{cm}^{3}\right)$ & 1 \\
$\geq 30$ & 0 \\
$<30$ & \\
Intraventrikular bleeding & 1 \\
Yes & 0 \\
No & \\
Infratentorial origin & 1 \\
Yes & 0 \\
No & \\
Age (years) & 1 \\
$\geq 80$ & 0 \\
$\leq 80$ & $0-6$ \\
Total ICH Score &
\end{tabular}

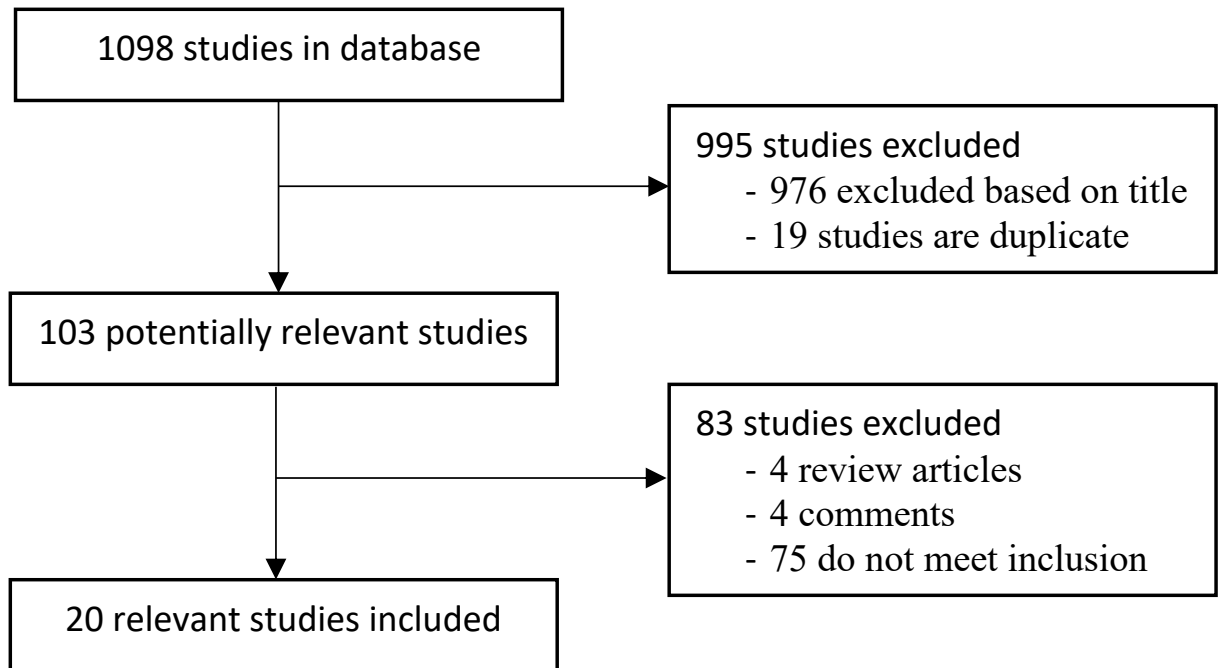

Figure 1 Selection of study used for meta-analysis

\subsection{0-Day Mortality Rate}

Eleven studies were included to analyze relationship of the ICH score and 30-day mortality rate. In this meta-analysis study, authors divided patients into 2 groups. The first group was patient with low ICH score (ICH score 0-2) and the second group was patient with high ICH score (ICH 
score 3-6). This division is based on research conducted by Rind et al. in 2016 which divided hemorrhagic stroke patient outcome based on their ICH score [8]. Analysis of ICH score and 30day mortality rate can be seen in Figure 2.

Table 2 Characteristic of the studies

\begin{tabular}{|c|c|c|c|}
\hline Study & $\begin{array}{c}\text { Publication } \\
\text { Year }\end{array}$ & Type of Study & $\begin{array}{c}\text { Number of } \\
\text { Patients }\end{array}$ \\
\hline Abdallah et al. [9] & 2018 & Cohort Prospective & 73 \\
\hline Chen et al. [10] & 2011 & Cohort Retrospective & 285 \\
\hline Chuang et al. [11] & 2009 & Cohort Retrospective & 304 \\
\hline Clarke et al. [12] & 2004 & Cohort Retrospective & 175 \\
\hline Esmael et al. [13] & 2015 & Cohort Prospective & 360 \\
\hline Garret et al. $[14]$ & 2013 & Cohort Retrospective & 501 \\
\hline Garton et al. [15] & 2019 & Cohort Prospective & 582 \\
\hline Godoy et al. [16] & 2006 & Cohort Prospective & 153 \\
\hline Hemphill et al. [17] & 2001 & Cohort Retrospective & 161 \\
\hline Houben et al. [7] & 2018 & Cohort Retrospective & 1232 \\
\hline Malinova et al. [18] & 2019 & Cohort Retrospective & 233 \\
\hline Muengtaweepongsa et al. [19] & 2013 & Cohort Retrospective & 66 \\
\hline Nisar et al. [20] & 2018 & Cohort Retrospective & 245 \\
\hline Parry-Jones et al. [21] & 2014 & Cohort Retrospective & 1364 \\
\hline Patriota et al. [22] & 2009 & Cohort Retrospective & 53 \\
\hline Puneeth et al. [23] & 2019 & Cohort Prospective & 617 \\
\hline Rahmani et al. [24] & 2018 & Cohort Prospective & 107 \\
\hline Safatli et al. [25] & 2016 & Cohort Retrospective & 342 \\
\hline Sandoval et al. [26] & 2007 & Cohort Prospective & 378 \\
\hline Weimar et al. [27] & 2006 & Cohort Prospective & 371 \\
\hline
\end{tabular}




\section{A. Cohort Retrospective Study}

\begin{tabular}{|c|c|c|c|c|c|c|c|c|c|c|}
\hline \multirow[b]{2}{*}{ Study or Subgroup } & \multicolumn{2}{|c|}{ High Score } & \multicolumn{2}{|c|}{ Low Score } & \multirow[b]{2}{*}{ Weight } & \multirow{2}{*}{$\begin{array}{c}\text { Odds Ratio } \\
\text { M-H, Random, } 95 \% \mathrm{Cl}\end{array}$} & \multirow{2}{*}{\multicolumn{3}{|c|}{$\begin{array}{c}\text { Odds Ratio } \\
\text { M-H, Random, } 95 \% \mathrm{Cl}\end{array}$}} & \\
\hline & Events & Total & Events & Total & & & & & & \\
\hline Clarke 2004 & 47 & 53 & 23 & 122 & $18.4 \%$ & $33.72[12.87,88.34]$ & & & & \\
\hline Hemphill 2001 & 57 & 67 & 11 & 85 & $18.7 \%$ & $38.35[15.23,96.55]$ & & & & \\
\hline Malinova 2019 & 70 & 169 & 0 & 64 & $7.3 \%$ & $91.40[5.56,1501.89]$ & & & & \\
\hline Meungtaweepongsa 2013 & 7 & 18 & 3 & 48 & $14.2 \%$ & $9.55[2.12,42.98]$ & & & & \\
\hline Nisar 2018 & 60 & 73 & 26 & 172 & $20.2 \%$ & $25.92[12.48,53.81]$ & & & & \\
\hline Safatli 2016 & 66 & 168 & 20 & 174 & $21.3 \%$ & $4.98[2.85,8.72]$ & & & $\rightarrow-$ & \\
\hline Total $(95 \% \mathrm{Cl})$ & & 548 & & 665 & $100.0 \%$ & $19.59[7.89,48.64]$ & & & & \\
\hline Total events & 307 & & 83 & & & & & & & \\
\hline $\begin{array}{l}\text { Heterogeneity: } \operatorname{Tau}^{2}=0.93 \text {; } \\
\text { Test for overall effect: } Z=6 \text {. }\end{array}$ & $\begin{array}{l}h_{i}^{2}=25.7 \\
1(P<0.0\end{array}$ & $\begin{array}{l}1, d f= \\
0001)\end{array}$ & $5(P=0.0$ & 001); $1^{2}$ & $=81 \%$ & & 0.01 & 0.1 & ${ }^{1} \mathrm{High} / \mathrm{CH}$ & $\begin{array}{l}0 \\
\text { Score }\end{array}$ \\
\hline
\end{tabular}

\section{B. Cohort Prospective Study}

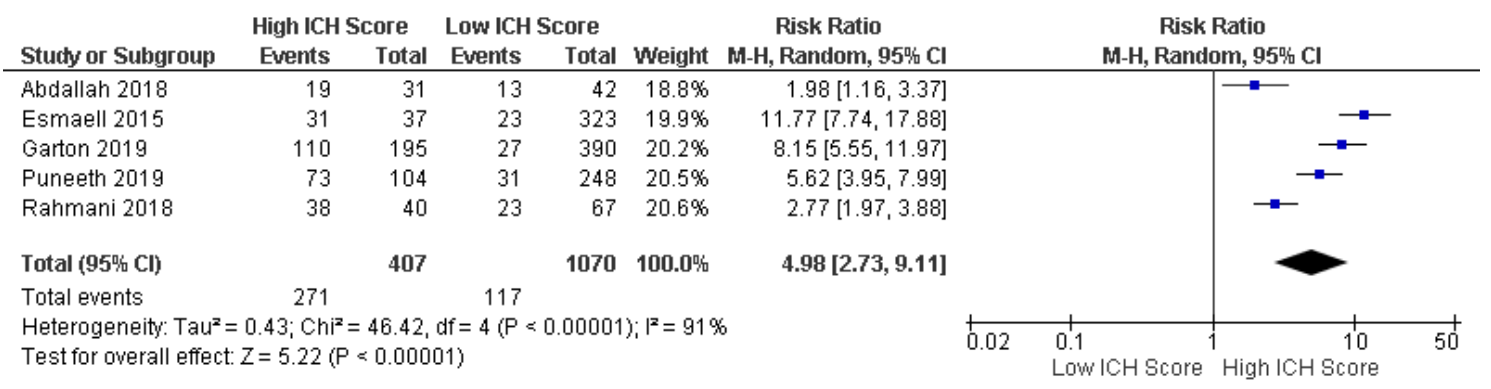

Figure 2. Forest plot Relationship of ICH Score and 30- Day Mortality Rate (A) Retrospective Study and (B) Prospective Study

The result of combined data from six retrospective studies (forest plot A) shows that ICH score had a significant relationship with 30-day mortality rate in hemorrhagic stroke patient. Total odds ratio obtained from this analysis is 19.59 with $95 \%$ confidence interval ranged from 7.89 to 48.64 $(\mathrm{p}<0.00001)$.

Data analysis of five prospective studies also yielded similar results. The total risk ratio of five combined data (forest plot B) is 4.98 with $95 \%$ confidence interval ranged from 2.73 to 9.11 $(\mathrm{p}<0.00001)$.

\subsection{Accuracy of ICH Score}

Eleven from 20 studies that included for this study were used to analyze accuracy of the ICH score in predicting mortality of hemorrhagic stroke patient. Studies used in this analysis had Area Under Curve (AUC) that used to determine the effect size. AUC value is within the range 0.5-1.0, where the minimum value represents the low accuracy and the maximum value represents perfect accuracy.

Based on data analysis of 11 combined data, ICH score had high accuracy in predicting 30-day mortality rate in hemorrhagic stroke patient. Total AUC obtained is 0.827 with $95 \%$ confidence interval ranged from 0.796 to $0.858(\mathrm{p}<0.001)$. Data analysis and the forest plot can be seen in Figure 3. 


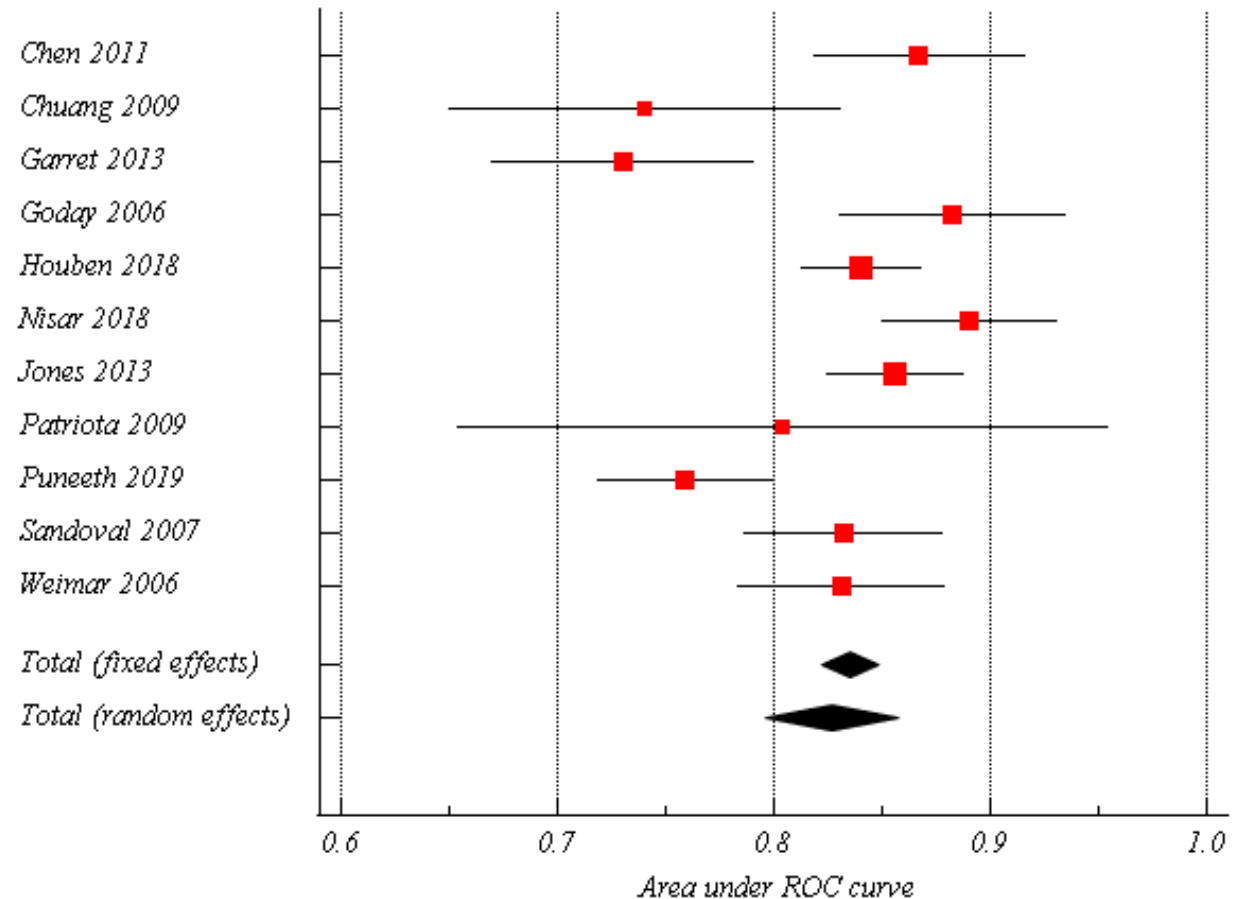

\begin{tabular}{|c|c|c|c|c|c|c|c|}
\hline \multirow[t]{2}{*}{ Study } & \multirow[t]{2}{*}{ ROC Area } & \multirow[t]{2}{*}{ Standard Error } & \multirow[t]{2}{*}{ 95\% CI } & \multirow[t]{2}{*}{$\mathbf{z}$} & \multirow[t]{2}{*}{$\mathbf{P}$} & \multicolumn{2}{|c|}{ Weight (\%) } \\
\hline & & & & & & Fixed & Random \\
\hline Chen 2011 & 0.867 & 0.0247 & 0.819 to 0.915 & & & 7.41 & 9.65 \\
\hline Chuang 2009 & 0.740 & 0.0459 & 0.650 to 0.830 & & & 2.15 & 6.07 \\
\hline Garret 2013 & 0.730 & 0.0306 & 0.670 to 0.790 & & & 4.83 & 8.55 \\
\hline Goday 2006 & 0.882 & 0.0265 & 0.830 to 0.934 & & & 6.44 & 9.31 \\
\hline Houben 2018 & 0.840 & 0.0140 & 0.813 to 0.867 & & & 23.08 & 11.53 \\
\hline Nisar 2018 & 0.890 & 0.0204 & 0.850 to 0.930 & & & 10.87 & 10.45 \\
\hline Jones 2013 & 0.856 & 0.0160 & 0.825 to 0.887 & & & 17.67 & 11.21 \\
\hline Patriota 2009 & 0.804 & 0.0765 & 0.654 to 0.954 & & & 0.77 & 3.15 \\
\hline Puneeth 2019 & 0.759 & 0.0206 & 0.719 to 0.799 & & & 10.66 & 10.41 \\
\hline Sandoval 2007 & 0.832 & 0.0232 & 0.787 to 0.877 & & & 8.40 & 9.93 \\
\hline Weimar 2006 & 0.831 & 0.0242 & 0.784 to 0.878 & & & 7.72 & 9.74 \\
\hline Total (fixed effects) & 0.835 & 0.00673 & 0.822 to 0.848 & 124.193 & $<0.001$ & 100.00 & 100.00 \\
\hline $\begin{array}{l}\text { Total (random } \\
\text { effects) }\end{array}$ & 0.827 & 0.0157 & 0.796 to 0.858 & 52.811 & $<0.001$ & 100.00 & 100.00 \\
\hline
\end{tabular}

Test for heterogeneity

Q

DF

Significance level $\quad \mathrm{P}<0.0001$

$\mathrm{I}^{2}$ (inconsistency) $77.18 \%$

$\mathbf{9 5 \%}$ CI for $\mathbf{I}^{2} \quad 59.29$ to 87.21

Figure 3. Forest Plot Accuracy of ICH Score 


\section{Discussion}

ICH score has five variables that used to predict mortality in hemorrhagic stroke patients. That are Glasgow Coma Scale score, bleeding volume, intraventricular bleeding, infratentorial origin and age. There have been many studies that discuss relationship of each variables with mortality rate in hemorrhagic stroke patients. In this study, we only analyze total ICH score relationship with mortality rate.

Using eleven studies with 2690 total sample, we found a significant correlation between ICH score and 30-day mortality rate (OR: $19.59 ; 95 \%$ CI: 7.89 to 48.64 , RR: $4.98 ; 95 \%$ CI: 2.73 to 9.11; $<<0.00001)$. In Malinova et al. [18] study, no mortality incidence in patient with low ICH score and more than half of patient with high ICH score experienced death. Study by Garton et al. [15] we found 110 cases of mortality from a total 195 patients with high ICH score compared with 27 cases of mortality from 390 total patients with low ICH score. In the Rahmani et al. [24] study, only 2 patients with high ICH score survive in 30 days interval.

This study also analyzes how accurate ICH score in predicting mortality. Of eleven studies used in this analysis, study by Nisar et al. [20] has the highest AUC value with 0.890 . The lowest value found in study by Garret et al. [14] with 0.730 . Total AUC value from this analysis is $0.827(95 \%$ CI: 0.796 to 0.858 ). These results indicate that ICH score has a high accuracy to predict mortality in hemorrhagic stroke patients.

\section{Conclusion}

In this study, there is a significant correlation between ICH score and 30-day mortality rate in hemorhagic stroke patient (OR: 19.59; 95\% CI: 7.89 to 48.64, RR: 4.98; 95\% CI: 2.73 to 9.11; $\mathrm{p}<0.00001)$. There is also found that ICH score was a precise grading scale for mortality in hemorrhagic stroke patient with 30 days interval (Total AUC : 0.827 ; 95\% CI: 0.796 to 0.858 ; $\mathrm{p}<0.001)$.

\section{REFERENCE}

[1] World Health Organization, "Stroke: a global response is needed," 2016. https://www.who.int/bulletin/volumes/94/9/16-181636/en/ (accessed Apr. 03, 2020).

[2] E. J. Benjamin et al., Heart Disease and Stroke Statistics-2019 Update: A Report From the American Heart Association, vol. 139, no. 10. 2019.

[3] R. R. V Krishnamurthi et al., "Global and regional burden of first-ever ischaemic and haemorrhagic stroke during 1990-2010)70089-5. Global and regional burden of first-ever ischaemic and haemorrhagic stroke during 1990-2010," Lancet. Glob. Heal., vol. 1, no. 5, pp. e259-e281, 2013, doi: 10.1016/S2214-109X(13)70089-5.Global.

[4] Kementrian Kesehatan RI, "Riset Kesehatan Dasar (Riskesdas)," Litbankes Kemenkes RI, 2018.

[5] S. T. Epple C, Brainin M, "Intracerebral hemorrhage," in Textbook of stroke medicine, 2nd 
ed., H. W. Brainin M, Ed. Cambridge University Press, 2013, pp. 188-206.

[6] N. Chaudhary, A. S. Pandey, X. Wang, and G. Xi, "Hemorrhagic strokePathomechanisms of injury and therapeutic options," CNS Neurosci. Ther., vol. 25, no. 10, pp. 1073-1074, 2019, doi: 10.1111/cns.13225.

[7] R. Houben, F. H. B. M. Schreuder, K. J. Bekelaar, D. Claessens, R. J. van Oostenbrugge, and J. Staals, "Predicting prognosis of intracerebral hemorrhage (ICH): Performance of ICH score is not improved by adding oral anticoagulant use," Front. Neurol., vol. 9, no. FEB, pp. 1-6, 2018, doi: 10.3389/fneur.2018.00100.

[8] M. A. Rind, M. Ali, M. Nazir, and S. Sheikh, "Validity of Intracerebral Haemorrhge Score in Predicting Prognosis of Hemorrhagic Stroke," vol. 11, no. 1, pp. 7-12, 2016.

[9] A. Abdallah et al., "Validation of the intracerebral hemorrhage score in Uganda: A prospective cohort study," Stroke, vol. 49, no. 12, pp. 3063-3066, 2018, doi: 10.1161/STROKEAHA.118.022057.

[10] H. S. Chen, C. F. Hsieh, T. T. Chau, C. D. Yang, and Y. W. Chen, "Risk factors of inhospital mortality of intracerebral hemorrhage and comparison of ICH scores in a Taiwanese population," Eur. Neurol., vol. 66, no. 1, pp. 59-63, 2011, doi: $10.1159 / 000328787$.

[11] Y. C. Chuang, Y. M. Chen, S. K. Peng, and S. Y. Peng, "Risk stratification for predicting 30-day mortality of intracerebral hemorrhage," Int. J. Qual. Heal. Care, vol. 21, no. 6, pp. 441-447, 2009, doi: 10.1093/intqhe/mzp041.

[12] J. L. Clarke, S. C. Johnston, M. Farrant, R. Bernstein, D. Tong, and J. C. Hemphill, "External validation of the ICH score," Neurocrit. Care, vol. 1, no. 1, pp. 53-60, 2004, doi: $10.1385 / \mathrm{NCC}: 1: 1: 53$.

[13] A. Esmael, M. Sherif, and M. Saad, "Prediction of 30-days Mortality of Intracerebral Hemorrhage by a Powerful but Easy to Use Intracerebral Hemorrhage Score," Int. Neuropsychiatr. Dis. J., vol. 6, no. 2, pp. 1-11, 2016, doi: 10.9734/indj/2016/22414.

[14] J. S. Garrett, M. Zarghouni, K. F. Layton, D. Graybeal, and Y. A. Daoud, "Validation of clinical prediction scores in patients with primary intracerebral hemorrhage," Neurocrit. Care, vol. 19, no. 3, pp. 329-335, 2013, doi: 10.1007/s12028-013-9926-y.

[15] A. L. A. Garton, V. P. Gupta, S. Sudesh, H. Zhou, B. R. Christophe, and E. S. Connolly, "The Intracerebral Hemorrhage Score: Changing Perspectives on Mortality and Disability," World Neurosurg., vol. 135, pp. e573-e579, 2020, doi: 10.1016/j.wneu.2019.12.074.

[16] D. A. Godoy, G. Piñero, and M. Di Napoli, "Predicting mortality in spontaneous intracerebral hemorrhage: Can modification to original score improve the prediction?," Stroke, vol. 37, no. 4, pp. 1038-1044, 2006, doi: 10.1161/01.STR.0000206441.79646.49.

[17] J. C. Hemphill, D. C. Bonovich, L. Besmertis, G. T. Manley, and S. C. Johnston, "The ICH score: A simple, reliable grading scale for intracerebral hemorrhage," Stroke, vol. 32, no. 4, pp. 891-896, 2001, doi: 10.1161/01.str.32.4.891.

[18] V. Malinova, B. Iliev, D. Mielke, and V. Rohde, "Intracerebral Hemorrhage-Score Allows a Reliable Prediction of Mortality in Patients with Spontaneous Intracerebral Hemorrhage Managed by Fibrinolytic Therapy," Cerebrovasc. Dis., vol. 48, no. 3-6, pp. 165-170, 2020, doi: $10.1159 / 000504246$.

[19] S. Muengtaweepongsa and B. Seamhan, "Predicting mortality rate with ICH score in Thai intracerebral hemorrhage patients," Neurol. Asia, vol. 18, no. 2, pp. 131-135, 2013.

[20] T. Nisar, A. Alchaki, and M. Hillen, "Validation of ICH score in a large urban population," Clin. Neurol. Neurosurg., vol. 174, no. August, pp. 36-39, 2018, doi: 10.1016/j.clineuro.2018.09.007. 
[21] A. R. Parry-Jones et al., "Accuracy and clinical usefulness of intracerebral hemorrhage grading scores: A direct comparison in a UK population," Stroke, vol. 44, no. 7, pp. 18401845, 2013, doi: 10.1161/STROKEAHA.113.001009.

[22] G. C. Patriota et al., "Determining ich score: Can we go beyond?," Arq. Neuropsiquiatr., vol. 67, no. 3 A, pp. 605-608, 2009, doi: 10.1590/S0004-282X2009000400006.

[23] P. U.M. et al., "Validation of ICH and ICH-GS Scores in an Indian Cohort: Impact of Medical and Surgical Management," J. Stroke Cerebrovasc. Dis., vol. 28, no. 8, pp. 22132220, 2019, doi: 10.1016/j.jstrokecerebrovasdis.2019.05.003.

[24] F. Rahmani, R. Rikhtegar, A. Ala, A. Farkhad-Rasooli, and H. Ebrahimi-Bakhtavar, "Predicting 30-day mortality in patients with primary intracerebral hemorrhage: Evaluation of the value of intracerebral hemorrhage and modified new intracerebral hemorrhage scores.," Iran. J. Neurol., vol. 17, no. 1, pp. 47-52, 2018, [Online]. Available: http://www.ncbi.nlm.nih.gov/pubmed/30186559\%0Ahttp://www.pubmedcentral.nih.gov/ articlerender.fcgi?artid=PMC6121209.

[25] D. A. Safatli, A. Günther, P. Schlattmann, F. Schwarz, R. Kalff, and C. Ewald, "Predictors of 30-day mortality in patients with spontaneous primary intracerebral hemorrhage," Surg. Neurol. Int., vol. 7, no. 19, pp. S510-S517, 2016, doi: 10.4103/2152-7806.187493.

[26] J. L. Ruiz-Sandoval, E. Chiquete, S. Romero-Vargas, J. J. Padilla-Martínez, and S. González-Cornejo, "Grading scale for prediction of outcome in primary intracerebral hemorrhages," Stroke, vol. 38, no. 5, pp. 1641-1644, 2007, doi: 10.1161/STROKEAHA.106.478222.

[27] C. Weimar, J. Benemann, and H. C. Diener, "Development and validation of the Essen Intracerebral Haemorrhage Score," J. Neurol. Neurosurg. Psychiatry, vol. 77, no. 5, pp. 601-605, 2006, doi: 10.1136/jnnp.2005.081117. 